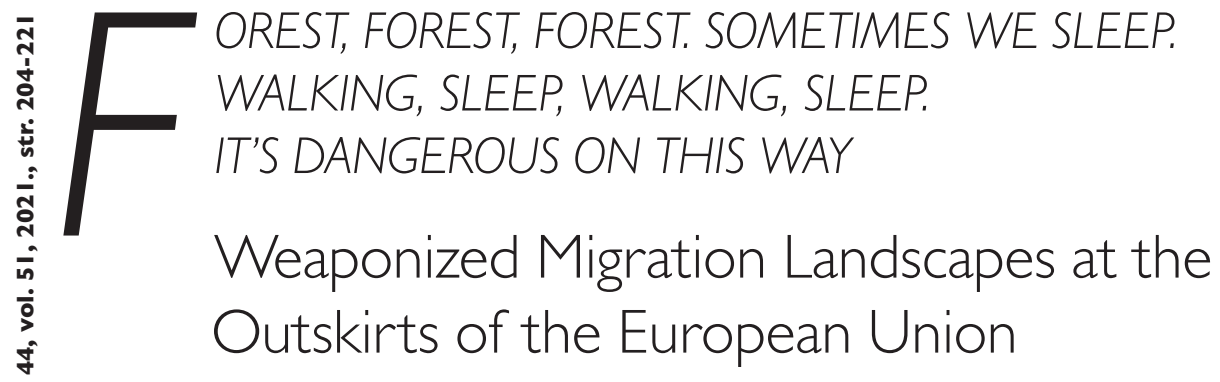

\author{
Marijana Hameršak \\ Institute of Ethnology and Folklore Research, Zagreb \\ Iva Pleše \\ Institute of Ethnology and Folklore Research, Zagreb
}

\begin{abstract}
Hidden migrant routes through Croatia lead through forest areas (among other types of terrain) which include those along state borders, but also forests in the interior of the territory. Those forests can variously be seen as shelters for migrants, albeit harsh, or as green tunnels leading to desired destinations, and as scenes of suffering and violence. This article approaches the forests in question as landscapes that have been transformed from a neutral natural environment into active factors for creating and maintaining border control regimes and deterring and expelling unwanted migrants. Based on our long-term field research and publicly available (archival, media and other) sources, we seek to document, interpret, and interconnect the objects and practices involved in constructing the forest as a hostile terrain and perilous environment for migrants, and as an important element in controlling unwanted migrations. These are, on the one hand, objects and practices that intervene into forests, such as setting up cameras or cutting down trees, and, on the other, interventions that take place in forests, such as police interception or expulsion. Apart from these external interventions, in this context of remodeling forests into dangerous environments, one can also discuss the role of nature itself and its characteristics, as well as the causes of why migrants find themselves in nature in the first place. Although, at first glance, it seems that people on the move choose the forest as the place and route of their movement of their own volition, they are pushed and expelled into these forests by exclusionary policies (visa regimes, asylum systems, etc.). This, ultimately, classifies forests in Croatia as weaponized landscapes of exclusion and death, such as the desert (e.g., De León 2015), mountain (Del Biaggio et al. 2020), maritime (e.g., Albahari 2015) or archipelago (Mountz 2017) landscapes.
\end{abstract}

Key words: forests, refugees, migrants, weaponized landscapes, pushback, Croatia, European border regime

Hidden migrant routes through Croatia lead through forest areas (among other types of terrain) which include those along state borders, but also forests in the interior of the territory. ${ }^{1}$ Unlike forests on the outer side of the European Union external borders, for example the forests around Bihać or Velika Kladuša in Bosnia and Herzegovina, which are places of forced immobility and where people gather their strength for yet another attempt to reach the West, forests in Croatia are primarily sites of move-

${ }^{1}$ This work has been fully supported by the Croatian Science Foundation under the project The European Irregularized Migration Regime at the Periphery of the EU: from Ethnography to Keywords (IP-2019-04-6642). 
ment, passage, and walking, serving as a sort of obstacle course that should be passed as quickly as possible by moving from one point to another. ${ }^{2}$ This division of forest areas separates the landscape, which in biological and geomorphological terms is usually considered as a whole (with regard to tree species, wildlife, relief, etc.). Thus, the forest is divided into parts which, due to being located in different social and geopolitical environments, can differ radically. For example, on the Bosnian side of the state border, Plješivica and the forests associated with it are locations with makeshift migrant camps, the so-called jungle camps and starting points for the game, i.e., attempts to clandestinely cross the border. On the Croatian side of the border, these forests are places of clandestine border crossings, but also of constant surveillance. ${ }^{3}$

The forests in question are both deciduous and coniferous, dense and sparse, some with tall trees, at high altitudes and in the lowlands, near populated places or cities, somewhat landscaped or more "virgin," with forest paths and roads or macadam roads. These forests include both groves and deep forests, forests crisscrossed with streams or rivers, but also man-made structures (shelters, huts, mountain lodges, vacation homes) and are, therefore, at different stages of anthropization. ${ }^{4}$ All these different types of forests provide protection to people on the move (cf. Czerny et al. 2021), which is a function they have served to various groups on the margins of society throughout history in these areas, providing cover for refugees during Ottoman rule (cf. Vlašić 2019: 82-83) and the Second World War (cf. Milošević 1981: 116-117), as well as for hajduks (cf. Vlašić 2019: 81-83) and partisans (cf. Kolar Dimitrijević 2008: 72). Aside from the fact that forest landscapes can variously be seen as refuges and shelters, albeit harsh ones, or as green tunnels leading to desired destinations, they can also be seen as sites of suffering and violence.

In this text, we will approach forests - both those associated with movement and those associated with immobility - as landscapes that have been transformed from a neutral natural environment into active factors for the creation and maintenance of border control regimes as well as for deterring and expelling unwanted migrants. We will approach them as landscapes that are oases of natural beauty, ideal for socalled active rest, walks, and hikes yet have been turned into places where people are injured, captured, humiliated, tortured, and subjected to suffering.

We will focus on the period following the closure of the Balkan corridor and mass, state-organized transit during the critical months of 2015 and 2016 (see Beznec et al. 2016, Bužinkić and Hameršak 2018), when the migrant movement be-

\footnotetext{
${ }^{2}$ Of course, in the broader context of the journey to Europe, which goes through many branching paths and in different directions and consists of plenty of backtracking, as well as more or less temporary states of immobility in addition to advancing towards the destination, the forests of Bosnia and Herzegovina are also places of transit, or at least they should be, from the perspective of migrants - just another section on a long and arduous journey.

${ }^{3}$ This shows the necessity of a transnational approach and research that transcends national borders at this level as well. The approach and research in question, on the one hand, try to follow the migration movement itself, and on the other, explore the different facets of the European migration control regime that are related on geopolitical locations and conditions.

${ }^{4}$ The forest as a jungle, which is a term used by at least one part of the migrants, refers, in addition to the forest and forest areas as described above, to green areas, but also to undeveloped or abandoned, unurbanized space in general. The term jungle, according to the interpretation of the name of the shanty town in Calais, comes from the Pashto word "jangal" (Agier et al. 2019: 2).
} 
came hidden again, and its routes numerous. Faced with a tightening border apparatus along the external EU border with Serbia, migrants opened new escape pathways (e.g., Stojić Mitrović et al. 2020). Today, they no longer enter Croatia primarily from Serbia, but rather from Bosnia and Herzegovina, which became part of the so-called migrant route from Greece to the centers of Europe. Thus, the movement discussed here additionally branches off and encompasses the area between Croatia and Slovenia which is distinguished by forests.

The following text, based on our long-term field research, but primarily on the analysis of publicly available (archival, media and other) sources, will seek to document, interpret, and interconnect objects and practices involved in constructing the forest as a hostile and dangerous environment for migrants as well as an important element in controlling unwanted migrations. These are, on the one hand, objects and practices that intervene into forests, such as setting up cameras or cutting down trees, and, on the other hand, interventions that take place in forests, such as police interception or expulsion. Apart from these external interventions, in this context of remodeling forests into dangerous environments, we can also discuss the natural environment itself and its characteristics, such as relief, wildlife, climate, and weather, all of which, taken together or individually, can be perilous to people on the move.

\section{Forests of surveillance}

In everyday perception, a "real" forest is a synecdoche for nature, in contrast to our crowded, busy, urbanized, technologically advanced, and constantly monitored society. But forests can also be a crucial part in sophisticated technological systems, and vice versa, as we are reminded, for example, by radars that tower above the forests near our cities. The forests of today, in addition to the immediately visible giant towers on the summits of hills and mountains, feature other more or less sophisticated and noticeable technological products. These include various kinds of cameras, from camera traps for scientific monitoring of animals to so-called hunting cameras and cameras set up with the purpose to control the external borders of the European Union.

However, in addition to cameras explicitly set up for monitoring the border and its forest areas, other cameras are also used for such a purpose. For example, a camera allegedly set up by hunters on Plešivica hill above Rupa, near the Croatian-Slovenian border, to monitor bear activities recorded a group of migrants who "took a break on the hill on their way across the border" in June 2019 (Žic s. a.). In September and October 2020, photographs taken in Gorski Kotar showed "groups of illegal migrants on the move" (Goreta 2020). These photographs were originally posted on the personal Facebook profile of a local, self-proclaimed border guard who "regularly publishes information on the movement of illegal migrants in that part of Croatia." 5

\footnotetext{
${ }^{5}$ A text with the heading "Nož pod vrat" ("Knife under the throat") and the title "Kolone izbjeglica prestravile Gorski kotar: grupe naoružanih ljudi pljačkaju planinare, slučajne prolaznike, provaljuju u vikendice...” " Refugees Terrorizing Gorski Kotar: Groups of Armed People Robbing Hikers, Passers-by, Breaking into Vacation Homes ...,"
} 
Although not much is known about the origin of the recordings from his statements, it can be assumed that these recordings come from the surveillance camera of the local forestry administration and that, just like the footage from the hunting camera on Plešivica, this is a case of unauthorized trafficking in recorded content. In order to protect against fires and prevent the theft of wood, illegal trash disposal, and similar activities, the state forest and woodland management company ("Hrvatske šume") places cameras in various locations in forests: on trees, near forest warehouses, along forest paths, and elsewhere. These strategically placed cameras, which allegedly react to any movement and send recordings to mobile devices operated by the company, should not be used, as stated by the company itself, for the purpose of "classic surveillance" or "control of people's movement" (Petranović 2015). However, as can be seen from the cases stated above, footage from cameras set up for other purposes is also used in some type of control or in an attempt to control movement, even unofficially, from below.

In this context, informal calls on social networks for the installation of cameras on private structures in forests are interpreted not only as calls for the protection of private property, but also as calls for a self-organized "defense" of borders. The idea of mass surveillance carried out from below is also inherent in the recordings made with private mobile phones circulating on social networks, often in groups that call for mass surveillance, but also those calling for armed and other types of confrontations with migrants. ${ }^{6}$ The material in question consists of photographs or videos of people on the move captured as they rest or pass by which are, more or less surreptitiously, taken by picnickers, hikers or passers-by and published in private and public groups. Judging by the number and types of cameras used to secretly record people on the move, their movement, intended to be hidden itself, is in fact constantly exposed to observation and recording.

Unlike the civilian monitoring of migrants, which is carried out "spontaneously," state-organized surveillance is part of a broader national and supranational migration control system aimed at securitization (Hess and Kasparek 2019; Huysmans 2006). The media and publicly available decisions on the allocation of resources from European funds, primarily the Internal Security Fund and the Schengen Facility, ${ }^{7}$ refer to cameras "built into" the forest, but also to mobile cameras and other recording and surveillance devices, i.e. day and night cameras, manual thermal imaging devices, infrared handheld devices of binocular design, FLIR mobile cameras, Bushnell

Goreta 2020), published on the Slobodna Dalmacija portal, is an example of the distinctly anti-migrant media articles that are otherwise less frequent in the so-called mainstream national media. The reason for publishing this article and, in addition to the conversation with the mentioned local border guard, the only source was the footage from the mentioned camera placed in the forest.

${ }^{6}$ In a group called "Gdje su viđeni migranti" ("Where migrants were seen"), which was still public at the time of publication in May 2019, one of the commentators recommended installing "WiFi cameras" on vacation homes and similar structures, which elicited a response from another commenter that one should "place mines all around the vacation home and just push the red button when you see a group on the camera" (Brakus 2019).

${ }^{7}$ Cf. https://eufondovi.mup.hr/eu-fondovi/financijski-okvir-2014-2020/odluke-o-dodjeli-financijskih-sredstava/189; https://eufondovi.mup.hr/UserDocsImages/dokumenti/Schengenski\%20instrument\%20-\%20popis\%20 projekata.pdf. 
cameras, thermal imaging cameras with a gyroscopic stabilizer, short-range sensor cameras, long-range cameras, drones, helicopters, trailers, and similar devices. As the list above suggests, evocative of a sort of "cabinet of curiosities," the means of visual technological surveillance of movement are numerous and diverse, and in response to the mobility of that movement, some of them are designed to be mobile themselves.

In the reports on pushbacks, which we use in this paper as sources for ethnographic statements, ${ }^{8}$ binoculars, cameras, drones, and helicopters are objects mentioned by people on the move in describing their journey through the forest, or, more precisely, their encounters with the police in the forest or the moments that immediately preceded them. Sometimes they refer to a device that they believe was used for capturing them, even though they did not actually see it, such as the camera they believe caught them sleeping in the forest (July 11, 2019). ${ }^{9}$ Similarly, they believe they were tracked with night binoculars, given that the officers seemed to have been waiting for them to exit the forest at the very spot where they eventually exited (March 13, 2019). They noticed cameras while on the move or resting, one of which was placed at eye-level in a tree (November 12, 2019), another one along the roadside, next to the forest (October 22, 2019), a third one in the top of a tree near the river at the location where the police caught them (April $27,2018)$. Sometimes they would spot lights, but did not know what device was their source, prior to their encounters with the police: the lights they saw just before they were approached by police officers in black uniforms could be lights coming from flashlights or cameras placed on the Slovenian side of the border river (October 16, 2018).

While the static cameras or binoculars carried by police officers (October 8, 2018) can be identified primarily by sight, hearing is the primary sense used for identifying other, related devices, especially at night: as they walked through the woods, around midnight, they heard a drone flying overhead, and soon they saw police officers running after them (September 29, 2018); shortly after dusk, they heard the buzzing of a drone which had targeted them from afar, it hovered above for a few minutes and after it had closed in on them - when they tried to run up a hill, they were ambushed by a group of "commandos" (October 15, 2019). Whether drones are discovered primarily by sound or by sight and flight (April 22, 2019), they are always associated with the arrival of the police or with a swiftly deployed ambush.

Knowing that the forests and other pathways used to reach their desired destinations are under technological surveillance, the people on the move adapt and change their strategies for border crossings based on their own experiences or those of oth-

\footnotetext{
${ }^{8}$ The reports in question come from a collection of reports on pushbacks published on the Border Violence Monitoring Network website, https://www.borderviolence.eu/violence-reports/.

${ }^{9}$ Here and elsewhere in the text where reference is made only to the date, the source is the aforementioned Border Violence Monitoring Network (https://www.borderviolence.eu/violence-reports/) collection in which the report is stored under the stated date. The examples are mostly stated in italics, not in quotation marks, because they are mostly paraphrases, not verbatim quotes from the original. Statements similar to the ones we cite in the paper can be easily found in other reports from this collection (with other dates), but we do not cite them here so that the large number of references does not make the text difficult to read. The Border Violence Monitoring Network has also published a special report, a preliminary overview on the role of technology in pushbacks from Croatia to Bosnia and Herzegovina and Serbia, which is referred to here (Sapoch and Barker s. a).
} 
ers. One testimony regarding an attempt to pass through Croatia points out that it important to try to cross the border in the early morning hours, given that police apprehension along the border at night is more violent and assisted by more surveillance technology: "Yes, because during night there are drones. You see them, I think there is ten. They see you. You cannot cross the border during night because when the police catches you in the night, they beat you a lot. They break you" (August 5, 2019).

The forest, therefore, from all the perspectives presented here, is demonstrably hyper-surveilled from the ground and air. This is a case of the so-called the paradox of "irregular" migration characterized by simultaneous movement on the sly and hypervisibility (Tazzioli 2018a: 12). In the context of border control, the means of visual technology are used in specific ways, primarily with the purpose of alarming the authorities and overcoming spatial distances. Based on information obtained through footage from various devices, interventions, captures, apprehensions, and pushbacks are also organized. However, some of the recordings are used primarily for documentary purposes. The literature on visual surveillance at the borders of the European Union (e.g., Tazzioli 2018a, Walters 2016) pays special attention to technological systems such as EUROSUR or JORA, which, unlike systems designed for notifying authorities in real-time, are focused on visual surveillance with the aim of archiving and analysis of future risks. In these instances, archiving is given priority over alarming, surveillance is subordinate to analysis or research, and immediate intervention gives way to experimentation and dystopian scenarios.

In addition to this advanced technological weaponizing of the forest, basic technical interventions are used for anti-migrant purposes in the field. One such intervention is the felling of the forest on Plješivica, which was reported in the Croatian and Bosnian media primarily in May 2020, mostly due to objections from Bosnia and Herzegovina that the Croatian forest management company is cutting down trees on the territory of Bosnia and Herzegovina. Although the felling of trees seems to, at least from a layman's perspective and to use a phrase from the Forest Act, "disrupt forest management and reduce the future value of the forest," it is not legally considered an anti-environmental act and devastation of forest given the institutions that implement these actions and its purpose. According to the Forest Act (official gazette "Narodne novine" no. 68/18), forests and forest lands owned by the Republic of Croatia can be excluded from a forest management area for "the purpose of state border control or ensuring the visibility of the border line" at the request of the "central body responsible for internal affairs." Therefore, the Ministry of the Interior, when asked about the felling of trees on the slopes of Plješivica, confirmed, using euphemisms, that the state forest management company "is carrying out certain activities in the border area, based on a request from the Police Directorate" and added that such "activities" were carried out "during the previous year as well, with the aim of better visibility regarding the protection and surveillance of the state border and the prevention of illegal entry into the Republic of Croatia." ${ }^{10}$

\footnotetext{
${ }^{10}$ Cf. https://www.rtl.hr/vijesti-hr/novosti/hrvatska/3818952/hrvatske-sume-krce-sumu-na-granici-s-bih-zbog-migranata-rtl-ov-boris-misevic-donosi-detalje/. We also contacted Hrvatske šume during our research on sev-
} 
It should be noted that the police referred to the so-called integrated border management (Miljuš 2020), a term that is historically strongly related to the reorientation of the European Union migration and border policies towards securitization and management strategies for directing the movement of people (cf. Karamanidou and Kasparek 2018). It is, however, an (almost) "empty signifier" (Karamanidou and Kasparek 2018: 18), an umbrella term for loosely related acts, policies and actors that includes "elements such as strong and regular risk analysis, improved inter-agency cooperation and the use of state-of-the-art technology" (European Commission 2015: 4). In Croatia, the implementation of the Integrated Border Management Strategy (official gazette "Narodne novine" no. 91/19), in the "inter-agency cooperation" of the Ministry of the Interior and the state companies for water management ("Hrvatske vode") and forest management ("Hrvatske šume"), is used as justification for systematically "cleaning" the terrain. From 2016 to 2018, in accordance with this policy, about $163 \mathrm{~km}$ of drainage canals were "cleaned" only in the area of the Vukovar-Srijem Police Administration, as well as numerous "rivers and streams along the natural border between the Republic of Croatia and Bosnia and Herzegovina" (Vlada 2018a: 72). The media reported on only some of these interventions, with varying degrees of public response. In addition to the above-mentioned felling of the Plješivica forest, we should also mention the felling of willow trees and other vegetation along the Una River, also on the border between Croatia and Bosnia and Herzegovina (Žada 2019).

Historically speaking, the strategic deforestation for "border management" purposes is a continuation of similar interventions conducted in these areas, for example completely clearing all vegetation along the railway, road, and military facilities in Gorski Kotar, which was undertaken by the Italian administration during the Second World War in order to prevent partisans from carrying out acts of sabotage and which allegedly involved cutting down 850 hectares of forest with a wood mass of $425,000 \mathrm{~m}^{3}$ (Klepac 1997: 53). Going further back in history, in the border area between Slavonia and the Ottoman Empire, the method of "cutting in" (zasjeka) was confirmed to be used (Andrić 2017: 73), which was also associated with tree felling. However, this method was not meant to create "empty space," but to place the cut trees as obstacles on forest roads. Like embankments made from earth, fallen trees and excavated ditches as artificially created border lines in the Slavonian-Turkish borderlands and elsewhere in the Hungarian-Croatian Middle Ages (Andrić 2017: 73), the placement of concrete blocks and other obstacles on roads, macadams, and forest roads due to the Schengen area (Vlada 2014, 2018b) is aimed at preventing the movement of people. Similarly, the bald line made on Plješivica by the state forest management company on the order of the Ministry of the Interior, visible from the air and from the base of the mountain, and even from the city of Bihać, is intended to stop the movement of unwanted passengers. This is not a physical obstacle that is difficult to cross, but a clear space where the enemy - albeit one which does not 
intend to occupy the territory - is easy to spot. The importance of better visibility is pointed out, for example, by the head of the Croatian Border Administration, while speaking about the surveillance of migrants located in Bosnia and Herzegovina. After migrants moved closer to the border with Croatia following the closure of some camps in Bosnia and Herzegovina, the surveillance is even better than before: "With our systems for detecting and monitoring migrants, we can clearly survey the situation and, based on these technical devices at our disposal, react in time" (HINA 2020). Or, as explicitly stated in the report on the implementation of the mentioned integrated management, this type of interventions contributes to the "visibility of the state border with the Republic of Serbia and Bosnia and Herzegovina, and the operational efficiency of technical equipment (especially thermal imaging systems), and the responsiveness of border police in combating illegal migration" (Vlada 2018a: 72). With the reference to technical devices and thermal imaging systems, the apparatus aimed at detecting people in forests is completed, while the technological interventions used for this purpose, numerous in type and quantity, prove to be dependent on historically tested, extensive, but technologically rudimentary interventions.

\section{Forests of capture and pushbacks}

In addition to various kinds of cameras as objects that come from outside the forest and are placed there by humans, the cutting of trees or placing obstacles as practices aimed at controlling unwanted movements, people on the move also directly encounter other people in the forest. When it comes to such "encounters," the media place particular focus, along with catching smugglers and busting smuggling rings (Večernji list 2020) and migrants breaking into vacation homes, hunting lodges, mountain lodges and other facilities (Mrvoš 2018), on rescue operations. "Police Boasts: Six Exhausted Migrants Rescued in Forest Near Plješevica” (D. B. 2019); "Police Rescues Migrants Suffering from Hypothermia Near Aljmaš" (Bradarić 2021); "Dramatic Rescue: Migrants Stuck in Deep Snow, Police Officers Carry Hypothermic Children in Their Arms" (Vijesti.hr 2019) - these are just some of the headlines in the domestic media which, in the tried and tested tradition of oxymoronic combination of compassion and repression (Fassin 2005), add a humanitarian note, using the spectacle of the rescue, to a context otherwise shaped almost exclusively as an issue of security.

Other sources, from regular monthly field reports from activists to investigative journalism reports with statements from victims, witnesses, doctors, and even police officers, ${ }^{11}$ and to our field insights, show that migrants' encounters with other people in the forest, primarily the police, exhibit other qualities, and that the forests in these

\footnotetext{
${ }^{11}$ For insight into some of the sources, see, e.g., the report The Asylum Work Group and the Counselling Office of Workers (2020) or the introduction to the Fourth Report on Illegal Pushbacks of Refugees from the Republic of Croatia (Are you Syrious et al. 2018).
} 
scenarios turn into scenes of capture, intimidation, humiliation and pushbacks, as opposed to rescues.

In the reports on pushbacks from Croatia to Bosnia and Herzegovina and Serbia mentioned earlier, which focus on encounters with the Croatian police, forests are singled out as one of the regular spatial elements, in addition to roads, railways, villages, or police stations. Unlike roads and settlements that are given names more frequently, such as the "road A1" (October 24, 2018), Korenica (April 15, 2019) or Slunj (December 31, 2019), the forests from these reports remain anonymous or are related to a toponym, such as the "forest near Vinkovci" (April 29, 2018) or the "forest near Karlovac" (July 7, 2018). Also, these forests are mostly not described at all, or are described only in the most basic terms, so it is not possible to know which and what kind of forests are in question based on the reports. However, the different "functions" of forests in this context can still be inferred. In addition to the already mentioned protection or shelter for people on the move and as a place of long journeys on foot, occasional waiting and struggles with nature, the forests are primarily presented in reports as a place of interception and capture, a prelude to expulsion and as a place of expulsion itself or literal pushback across the green border. The reports clearly show that all forests, from those within the territory to those along the borders with the neighboring countries to the east and west, can be places of capture and the preludes to pushbacks, while the locations of final expulsion are always only forests on the external border of the European Union, along the border with Croatia's eastern neighbors.

Thus, for instance, a forest near the border (March 6, 2019), a small road in the forest (August 2, 2017), a forest path (February 22, 2020), forest near Road no. 1 (August 13, 2018) and other forests or areas near forests are locations where police intercepts or waits in ambush (January 5, 2019), detects (July 5, 2018), finds (September 1, 2017), catches (October 18, 2018) and arrests (February 16, 2018) people on the move. One such location, more precisely a location designated for police waiting for migrants, is the mountain lodge on Risnjak in Gorski Kotar as presented in a text of an anonymous mountaineer, with whom we spoke in person: "When we entered the living room of the mountain lodge, I saw an automatic rifle on a table and two special force officers talking to the manager of the lodge. At first, we did not understand what was happening, but we soon learned that the special police had become part of everyday life in the lodge. We did not receive any official explanation as to why there were armed special forces in full combat gear among us, but the manager of the home told us that 'they are protecting us from refugees"” (s. n. 2019). That evening, the special forces did encounter migrants: "Several of them arrived and asked for water, and a younger couple immediately handed them a bottle, so they sat on the floor exhausted and drank the water. The young couple did not even have time to warn them that there were special forces nearby, as the special forces rushed out after one of the people who had seen the arrival of the refugees reported their presence to them" (s. n. 2019).

Just as cameras in forests or near forests signal to people on the move the possible quick arrival of the police, as described in the previous section, so can encounters 
with people, in the forests or near them, with local people (July 23, 2018), hunters (August 13, 2018), or with visitors of mountain lodges, as described above, also be seen as warning signs. One can see that people on the move perceive such encounters as a possible precursor to police action based, for example, on the encounter between a hiker and migrants on a hiking trail. While describing the event, she told us, among other things: one of them, their guide, dropped to the ground, held his hands as if praying, and begged us not to call the police. This was, she says, body language intended to show non-aggression. Another hiker told us how she witnessed the arrival of migrants in a mountain lodge: the custodian told her not to go out, she called these people to give them food, and she went to call the special forces, but the people figured out was going on, so they just continued on.

Running into people in forests, near forests, or elsewhere along the migrant trails does not necessarily involve reports to the police. Sometimes, in fact, these encounters are more friendly in nature. The hiker who described her encounter with a group of people on the hiking trail and her communication with their guide, told us that she and her companion, despite feeling uneasy because of the sudden and unexpected encounter in the forest, gave the guide some water they had with them and then continued on their way. Similar recounts, although much rarer than ones that are antimigrant, can be found in the media, in articles about migrant movements in Croatia. For example, one person states the following when looking back at their meeting with migrants in the forests around Rijeka: "Tired, exhausted, dirty. They asked for water because they were thirsty. We gave them something to drink and some food and they went on their way" (Glavan 2018). One description from a pushback report, from the perspective of people on the move, also points to behavior that, had it not been for the criminalization of aid and solidarity and the public persecution of migrants, ${ }^{12}$ would have been expected, especially taking into account the tradition of helping troubled travelers: ${ }^{13}$ We met some nice men cutting wood in the jungle who gave us food and water and pointed us in the right direction. The description of this encounter ends with a sentence that suggests that the woodcutters left a special impression on people on the move: "We call this the woodcutters' road" (October 25, 2019).

Just as encounters between people on the move and other people in the forest or elsewhere on the road may or may not ultimately lead to capture and then expulsion, the forest itself, or its terrain, soil configuration and similar factors, as we have seen, can be an element that can help or hinder the police. Reports sometimes suggest that the forest and its trees provided protection from view and helped the migrants escape from the police (August 25, 2018). But the reverse is also sometimes true, when the configuration of the forest proves helpful to the catchers (October $15,2019)$. The previously mentioned text of the hiker who described the action of the special police at the mountain lodge also reveals the role of nature and soil con-

\footnotetext{
${ }^{12}$ Cf. reports (Ćuća, 2019) for Croatia or Europe (Fekete et al., 2017) and articles by, e.g. Pallister-Wilkins (2018), Tazzioli (2018b), Zorn (2021).

${ }^{13}$ For traditional and otherwise established principles of helping travelers in distress or hospitality in general cf. e.g. Lipovec Čebron et al. 2020, Rozakou 2012 and 2016.
} 
figuration, this time in catching people: "They ran out with batons yelling 'lay on the ground' and started beating them. The refugees began to flee, at which point one (or more) police officers started firing from their weapons, above their heads. In that insane situation, overcome with fear, one of the refugees ran down the ravine and, according to an eyewitness, injured himself quite badly (we can't be sure how extensive the injuries were because none of us were allowed to leave the lodge after that) - and was one of the six that were captured (as we learned from the special forces later and during the next day)" (s. n. 2019).

After capture, which is often accompanied by shouting and shooting in the air (January 5, 2019), the location of the "encounter" with the police turns into a place of further police treatment of the people that were caught. We have reports of police, for example, forcing people to kneel in the snow (January 5, 2019), or to sit on the ground wet with rain (January 20, 2019); questioning and searching people (August 29, 2018), forbidding people to speak (August 13, 2018), taking away documents, phones, money and other property (October 8, 2018), smashing phones (August 13, 2018) and chargers, setting fire to sleeping bags and backpacks (March 30, 2019), using pepper spray (February 7, 2019) and electric shocks (March 26, 2019), threatening with weapons (October 23, 2018), letting dogs near them (June 20, 2019), physically assaulting people (August 13, 2018) and beating people (October 19, 2018). While some of these elements, such as interrogation and frisking, are mostly reserved for interception and capture, some of them, such as burning sleeping bags (April 15, 2019) or clothing (January 5, 2020), also occur during the final part of operation pushback when people are literally expelled from Croatia and even more intense violence than at the location of the arrest is committed.

What follows the capture, immobilization and police treatment at the location of arrest, and before the expulsion itself, is the transfer of migrants to the green border. Sometimes it is performed as a direct transfer (June 25, 2019), and sometimes it includes additional "stops," a police station or, for example, an improvised structure, a garage which, as one of the reports states, is used to detain people on the move, especially when performing a pushback. It is dirty, there is no water nor food, no toilets, only dirty bottles on the cold, bare concrete ground (March 15, 2019). ${ }^{14}$ Sometimes the transfer starts outside Croatia, in Slovenia (September 8, 2020) or Italy (August 5, 2019) and afterwards, in a so-called chain pushback, it includes several stops, for example, a camp in Italy (August 5, 2019), a police station in Slovenia, followed by a location where the Slovenian police hands the people over to the Croatian police, then a police station in Croatia (January 5, 2020), etc. The ride in the police van itself, which is often described as wild and reckless, with a lot of acceleration and sudden braking in the reports (October 16, 2020), takes less time when the people on the move are caught near the border and the locations on the green border that are "reserved" for expulsion, and longer when people are caught deeper in the territory of Croatia or have already reached the border with Slovenia (January 5, 2020). The driving style that causes nausea and vomiting in passengers (January 10,2019) and other actions

\footnotetext{
${ }^{14}$ For more info, cf. the text "Garaža za mučenje migranata” (Garage for Torturing Migrants) (Perić 2019).
} 
such as additionally cooling the air in the van during the cold months in winter (February 6,2019) imply treatment aimed at intentional exhaustion and torture.

The final act of expulsion begins with removing people from the van at the green border where, for example, according to reports, a larger or smaller group of people in black uniforms waits for them (October 26, 2019) with masks covering their faces (January 10,2019), and batons or other types of weapons, such as branches as handy weapons taken from nature (October 22, 2019). Descriptions of violent expulsion are numerous, difficult and nauseating, and often differ only in minute details. After being thrown out of the van, the people pass through a police corridor one by one (October 15,2019 ) or enter a police circle (February 27,2019 ) and are hit with fists, hands, feet and batons (February 6, 2019). And after they are run off from that location, they sometimes have to go back again, wet, frostbitten, tired, and disoriented, as described in the following report: The three of them ran about 50 meters, then stopped and hid themselves. They waited for the officers to leave and then returned to the pushback location to take their backpacks out of the river where the officers had thrown them. When they were on the other side of the border again, they saw a car coming to the same place and the police beating three other people (February 6, 2019).

During pushbacks, as the previous quote suggests, the natural location where the pushback takes place is used. People are thus forced into water - a river (June 25,2019 ), a small river (December 8, 2019) or a stream (January 10, 2019) - which also represents the border they have to cross and another location of violence: officers force them to move towards the stream, hit their legs and backs with batons to make them go faster (January 29, 2019) or kick them into the river, shouting Go Bosnia! Fuck you! (January 5, 2019). Even those who manage to escape the officers and thus avoid their blows, still fall into the water when fleeing (January 18, 2019). Aside from water as a natural barrier that supports the violent action of uniformed people, other tools from nature are also mentioned in the reports, such as cut trees used to stop people who try to run: "The first police officer starts beating you. And you run. And you don't see the obstacle here and you fall down and the other starts beating you" (June $25,2019)$. In this manner, other elements from nature, along with rivers, streams or steep hills at the border line where people are pushed, are transformed into "natural tool of assistance for the police officers," which is a description of the landscape along the border from one of the activist reports on pushbacks in which the role of nature in the expulsion of migrants from Croatia to Bosnia and Herzegovina and Serbia is emphasized (Augustova et al. [2018]: 12).

However, regardless of the role of nature in violence against migrants and its prominence, it should be emphasized that in all of the cases mentioned, other people are the primary and unambiguous agent committing violence against migrants, monitoring them, intercepting, capturing and expelling them, and by doing so they put them in perilous situations. In contrast, in some cases it is more difficult to discern the role of man, and thus the role of society and politics, in the suffering that is related to nature. For instance, when pushback reports describe cold and snowy conditions, they are not automatically associated with human activity, but are perceived 
as limitations on movement imposed by nature: it was very difficult to walk because the snow was half a meter high (January 16, 2019). Due to the extreme cold, taking a break becomes dangerous, and drinking water freezes (January 10,2019). One of the reports states "we would melt the snow to drink the water" (January 10, 2019). Wet clothes, shoes, personal belongings, even sleeping bags (January 18, 2019) represent the marks of nature on the arduous journey, but also on its stops and locations where migrants have to wait: whether waiting for a guide, smuggler, or better weather conditions in a Croatian forest or waiting and preparing for another game in a Bosnian forest where they also sleep on the ground, warm themselves by the fire, lack food, and get wet in the snow and rain. We dedicate the concluding part of this paper to the often seemingly non-existent role of man and the blurred chains of responsibility in the suffering on the migrant journey in "nature."

\section{Forests of suffering}

On Saturday, August 11,2018, a group of people arrived on foot in Drežnica, a village on the southeastern border of Gorski Kotar towards Lika in Croatia, bought some basic groceries and water in a local store and continued further west. By evening, however, they "only reached the hamlet of Tomići and decided to spend the night in the woods 5 kilometers away" (Aljazeera 2018a). A landslide occurred at the site during the night, killing two young men from the group. One, who was hit in the chest and abdomen according to the coroner, was killed on the spot, and the other subsequently bled to death. The cause of death of these two young men would be treated as an accident in official statistics. Violent death, even one caused by an accident, unlike so-called natural death, is a consequence of an "action of some external cause" (Erceg and Miler Knežević 2019: 11). In the case of the migrants from the Drežnica forest, the landslide was triggered, according to one interpretation, by rain (Aljazeera 2018a), and according to another, by an animal (Karakaš Jakubin 2018), which are both natural elements and thus natural causes of death.

Weather conditions, vegetation, terrain configuration, wild animals, insects, etc., are all considered "natural elements," in contrast to social and cultural elements of the world in which we live and are, to a large extent, independent of them. Unlike the direct violence of the security-repressive apparatus in which the human role is clearly visible, the responsibility for injuries and deaths in the environment of nature is not attributed to human action. The suffering of migrants in nature - of which death is only the most extreme - is interpreted as a consequence of nature and the conditions in which people on the move have found themselves. Thus, the television report, based on which we described one part of the journey and suffering of a group of migrants near Drežnica, singles out nature, more precisely the forest, as a source of danger to those who are not used to it, and notes that the forest, "although it appears tame," is actually "very dangerous especially in times of rain. Landslides and falling trees are an everyday occurrence ( ... ) and it is practically impossible to pass through these forests and survive in them during the winter" (Aljazeera 2018a). 
What the discourse on the vulnerability of migrants to nature, for example from the Balkan winter as their enemy (SRNA 2020) or numerous rivers as insurmountable obstacles to migrant movement (Aljazeera 2018b), does not recognize, even from a position of humanistic empathy which strives for benevolence towards people on the move, are the causes of why migrants find themselves in nature in the first place. Why do migrants walk the forest roads for days? Why do they use caves and foothills as shelters? Why do they wade through rivers or swim across them tied with ropes? And finally, why did so many of them drown in rivers on their way through Croatia, die in a fall, or die of hypothermia and exhaustion $?^{15}$

Although, at first glance, it seems that people on the move choose the forest as the place and route of their movement of their own volition, they are pushed and expelled into these forests by exclusionary policies (border systems and hierarchies of affiliation and citizenship, visa regimes, asylum systems, etc.). They are consciously and deliberately left to that potentially perilous nature, or rather, delivered into it. Thus, the elements of nature, along with the interventions and surveillance and capture systems discussed in this text, even when they have nothing to do with social elements at first glance, prove to be closely related to human action and a part of the social and political production of exposing migrants to potentially dangerous nature (Schindel 2019). This, ultimately, classifies forests in Croatia as weaponized landscapes of exclusion and death, such as the desert (e.g., De León 2015), mountain (Del Biaggio et al. 2020), maritime (e.g., Albahari 2015) or archipelago (Mountz 2017) landscapes on some other meridians. To put it concisely, they are landscapes that are reshaped and used as one more weapon in the obsessive "fight" against "illegal migration." This function, however, is hidden behind, for example, the previously highlighted occasional rescue operations, as well as behind the dehistoricized and depoliticized constructs of "nature." Such generally accepted understandings of nature, as summarized by Estela Schindel (2019), obscure the moral responsibility of individuals, policies, and societies for the suffering of migrants in nature by linking that suffering to supposedly neutral natural forces. But what is presented as a neutral natural environment, as we have tried to show in this text, is an active factor of mobilization for the purpose of exclusion and removal of the unwanted.

Translated by Juraj Šutej

\section{REFERENCES}

Agier, Michel, Yasmine Bouagga, Maël Galisson, Cyrille Hanappe, Mathilde Pette and Philippe Wannesson. 2019. The Jungle. Calais's Camps and Migrants. Cambridge and Medford: Polity Press. https://doi.org/10.3917/puf. agier.2018.01

Albahari, Maurizio. 2015. Crimes of Peace. Mediterranean Migrations at the World's Deadliest Border. Philadelphia: University of Pennsylvania Press.

\footnotetext{
${ }^{15}$ See the Map Border Deaths along the Balkan Migratori Trail: https://erim.ief.hr/publikacije/map-of-borderdeaths/.
} 
Aljazeera. 2018a. "Drežnica. Pogibja migranata u odronu šume i kamenja” (Drežnica. Migrants Die in Landslide and Rockslide). Aljazeera, August 13. https://balkans.aljazeera.net/videos/2018/08/13/dreznica-pogibja-migranata-u-odronu-sume-i-kamenja (accessed 6. 4. 2021.).

Aljazeera. 2018b. "Kako izgleda opasna izbjeglička ruta preko $\mathrm{BiH}$ i Hrvatske" (What a dangerous refugee route through B\&H and Croatia looks like). Aljazeera, May 9. https://balkans.aljazeera.net/videos/2018/05/09/ kako-izgleda-opasna-izbjeglicka-ruta-preko-bih-i-hrvatske?page=1?gb=true (accessed 6. 4. 2021.).

Andrić, Stanko. 2017. “Šuma Garavica i 'ničija zemlja’ na slavonsko-turskom pograničju u 16. i 17. stoljeću” (Garavica Forest and 'No Man's Land' on the Slavonian-Turkish Border in the 16th and 17th Centuries). In Slavonske šume kroz povijest (Slavonian Forests Through History). Dinko Župan and Robert Skenderović, eds. Slavonski Brod: Hrvatski institut za povijest, Podružnica za povijest Slavonije, Srijema i Baranje, 61-117.

Are you Syrious, Centar za mirovne studije, Incijativa Dobrodošli, No Name Kitchen. 2018. Report on Illegal Pushbacks of Refugees from the Republic Of Croatia. http://welcome.cms.hr/wp-content/uploads/2018/02/ Fourth-Report-on-Illegal-Pushbacks 01032018.pdf (accessed 6. 4. 2021.).

Augustova, Karolina, Anaïs Thévenot, Jack Sapoch and Alba Diez Arrea. [2018]. "Border Violence on the Balkan Route. People Trying to Reach Asylum in the EU Violently Pushed from Croatia and Slovenia to Serbia and Bosnia-Herzegovina, May 2017 - December 2018.” No Name Kitchen, SOS Velika Kladuša, Balkan Info Van. http://www.nonamekitchen.org/reportes-de-violencia/ (accessed 6. 4. 2021.)

Beznec, Barbara; Marc Speer and Marta Stojić Mitrović. 2016. Governing the Balkan Route. Macedonia, Serbia and the European Border Regime. Belgrade: Rosa Luxemburg Stiftung Southeast Europe.

Del Biaggio, Cristina; Leila Giannetto and Camille Noûs, eds. 2020. Refugiées et montagne / Refugees and Mountain. Journal of Alpine Research / Revue de géographie alpine, special issue, 108-2. https://doi.org/10.4000/ rga.7267

Border Violence Monitoring Network, s. a. Testimonies Database. https://www.borderviolence.eu/violence-reports/ (accessed 6. 4. 2021.).

Bradarić, Branimir. 2021. "Policija spasila pothlađene migrante kod Aljmaša, među njima i djeca" (Police Rescue Hypothermic Migrants Near Aljmaš, Including Children). Večernji list, February 13, 2021. https://www.vecernji.hr/vijesti/policija-spasila-pothladene-migrante-kod-aljmasa-medu-njima-i-djeca-1468650 (accessed 6. 4. 2021.).

Brakus, Ana. 2019. “'Gdje su viđeni migranti' - javna FB grupa puna prijetnji koju MUP ignorira” ('Where Migrants Were Seen' - Public FB Group Full of Threats Ignored by the Ministry of the Interior). Faktograf, June 11, 2019. https://faktograf.hr/2019/06/11/gdje-su-videni-migranti-javna-fb-grupa-puna-prijetnji-koju-mup-ignorira/?fbclid=IwAR0JLJbJkICUY_WnN67ehZBkW4iEGS3sesb_FADfX72T9LIFvnDHA0-Vtqk (accessed 6. 4. 2021.).

Bužinkić, Emina and Marijana Hameršak, eds. 2018. Formation and Disintegration of the Balkan Refugee Corridor. Camps, Routes and Borders in the Croatian Context. Zagreb and Munich: Institute of Ethnology and Folklore Research, Centre for Peace Studies, Faculty of Political Science University of Zagreb - Centre for Ethnicity, Citizenship and Migration, bordermonitoring.eu e.V.

Czerny, Sarah; Marijana Hameršak, Iva Pleše and Sanja Bojanić. 2021. "Can the Forests be Xenophobic? Migrant Pathways through Croatia and the Forests as Cover”. Manuscript for the workshop Xenophobic Landscapes (January 14, 2021.).

Ćuća, Ana. 2019. Criminalisation of Solidarity. CROSOL and CMS. https://www.cms.hr/system/article_document/doc/616/CPS_Policy_brief_Criminalisation_of_solidarity.pdf (accessed 6. 4. 2021.).

D. B. 2019. "Policija se pohvalila. Spašeno šestero iscrpljenih migranata u šumi kod Plješevice" (Police Boasts. Six Exhausted Migrants Rescued in the Forest Near Plješevica). Dnevnik.hr, August 7. https://dnevnik.hr/vijesti/ hrvatska/policija-se-pohvalila-spaseno-sestero-iscrpljenih-migranata-u-sumi-kod-pljesevice---570835.html (accessed 6. 4. 2021.).

De León, Jason. 2015. The Land of Open Graves. Living and Dying on the Migrant Trail. Oakland: University of California Press.

Erceg, Marijan and Ana Miler Knežević. 2019. “Izvješće o umrlim osobama u Hrvatskoj u 2018. godini” (Report on Deaths in Croatia in 2018). Hrvatski zavod za javno zdravstvo (Croatian Institute for Public Health). https:// www.hzjz.hr/wp-content/uploads/2019/09/Bilten_Umrli-_2018-1-1.pdf (accessed 6. 4. 2021.).

European Commission. 2015. "Communication From the Commission to the European Parliament and the Council. A European Border and Coast Guard and Effective Management of Europe's External Borders". $\operatorname{COM}(2015) 673$ final. https://eur-lex.europa.eu/legal-content/EN/TXT/PDF/?uri=CELEX:52015DC06 $73 \&$ from $=\mathrm{EN}$ (accessed 6. 4. 2021.).

Fassin, Didier. 2005. “Compassion and Repression. The Moral Economy of Immigration Policies in France”. Cultural Anthropology 20/3: 362-387. https://doi.org/10.1525/can.2005.20.3.362

Fekete, Liz, Frances Webber and Anya Edmond-Pettitt. 2017. Humanitarianism. The Unacceptable Face of Solidarity. London: Institute of Race Relations. https://s3-eu-west-2.amazonaws.com/wpmedia.outlandish.com/ irr/2017/11/10092853/Humanitarianism_the_unacceptable_face_of_solidarity.pdf (accessed 6. 4. 2021.). 
Glavan, Marinko. 2018. “'Da sam nešto i vidjela, ne bih vam rekla'. Lokalni stanovnici pomažu migrantima u šumama oko Rijeke” ('Had I seen something, I wouldn't have told you'. Locals Help Migrants in Forests Around Rijeka). Novi list, August 15. https://www.novilist.hr/novosti/hrvatska/da-sam-nesto-i-vidjela-ne-bih-vam-rekla-lokalni-stanovnici-pomazu-migrantima-u-sumama-oko-rijeke/ (accessed 6. 4. 2021.).

Goreta, Mirela. 2020. "Nož pod vrat. Kolone izbjeglica prestravile Gorski kotar. Grupe naoružanih ljudi pljačkaju planinare, slučajne prolaznike, provaljuju u vikendice..." (Knife Under the Throat. Refugees Terrorizing Gorski Kotar. Groups of Armed People Robbing Hikers, Passers-by, Breaking into Vacation Homes ... ). Slobodna Dalmacija, November 16. https://slobodnadalmacija.hr/vijesti/hrvatska/kolone-izbjeglica-prestravile-gorski-kotar-grupe-naoruzanih-ljudi-pljackaju-planinare-slucajne-prolaznike-provaljuju-u-vikendice-1057938 (accessed 6. 4. 2021.).

Hess, Sabine and Bernd Kasparek. 2019. "The Post-2015 European Border Regime. New Approaches in a Shifting Field." Archivio Anthropologico Mediterraneo 22/21(2). http://journals.openedition.org/aam/1812 (accessed 6. 4. 2021.). https://doi.org/10.4000/aam. 1812

HINA. 2020. "Ničeno: Pritisak migranata na hrvatsku granicu bit će jednak, s obzirom da je jednaki broj migranata, ali da su fizički nešto bliže granici” (Ničeno: The pressure of migrants on the Croatian border will remain the same, given that the number of migrants is the same, but that they are physically somewhat closer to the border). Slobodna Dalmacija, October 1. https://slobodnadalmacija.hr/vijesti/hrvatska/niceno-pritisak-migranata-na-hrvatsku-granicu-bit-ce-jednak-s-obzirom-da-je-jednaki-broj-migranata-ali-da-su-fizicki-nesto-blize-granici-1048082 (accessed 6. 4. 2021.).

Huysmans, Jeff. 2006. The Politics of Insecurity. Fear, Migration and Asylum in the EU. London, New York: Routledge. https://doi.org/10.4324/9780203008690

Karakaš Jakubin, Hajdi. 2018. "Foto: Reporteri Jutarnjeg na mjestu strašne tragedije kod Ogulina. Na dvojicu mladića usred noći srušila se stijena i smrskala ih” (Photo: Jutarnji Reporters at the Site of Terrible Tragedy Near Ogulin. A Boulder Collapsed on Two Young Men in the Middle of the Night and Crushed Them). Jutarnji list, August 12. https://www.jutarnji.hr/vijesti/hrvatska/foto-reporteri-jutarnjeg-na-mjestu-strasne-tragedijekod-ogulina-na-dvojicu-mladica-usred-noci-srusila-se-stijena-i-smrskala-ih-7714677 (accessed 6. 4. 2021.).

Karamanidou, Lena and Bernd Kasparek. 2018. "Border Management and Migration Control in the European Union". Respond Working Papers Paper 14.

Klepac, Dušan. 1997. Iz šumarske povijesti Gorskoga kotara u sadašnjost (From the Forestry History of Gorski Kotar to the Present). Hrvatske šume: Zagreb.

Kolar-Dimitrijević, Mira. 2008. "Kratak osvrt na povijest šuma Hrvatske i Slavonije od 1850. godine do Prvoga svjetskog rata" (A Brief Review of the History of the Forests of Croatia and Slavonia from 1850 to the First World War). Ekonomska i ekohistorija 4/4: 71-93.

Lipovec Čebron, Uršula, Eva Fekonja and Tina Ivnik. 2020. "Criminalized hospitality: The case of Velika Kladuša”. Glasnik Etnografskog instituta SANU 66/2: 397-418. http://www.doiserbia.nb.rs/img/doi/03500861/2020/0350-08612002397L.pdf (accessed 6. 4. 2021.). https://doi.org/10.2298/GEI2002397L

Milošević, Slobodan D. 1981. Izbeglice i preseljenici na teritoriji okupirane Jugoslavije 1941. - 1945. godine (Refugees and Migrants on the Territory of Occupied Yugoslavia in 1941-1945). Belgrade: IRO Narodna knjiga and Institut za savremenu istoriju.

Miljuš, Dušan. 2020. "Svakodnevno stižu stotine migranata. Posječeno 10-ak km šume uz granicu kako bi hrvatska policija nadzirala izbjeglice" (Hundreds of Migrants Arriving Every Day. About $10 \mathrm{~km}$ of Forest Along the Border Cut Down so the Croatian Police Can Monitor Refugees). Jutarnji list, June 9. https://www.jutarnji. $\mathrm{hr} /$ vijesti/hrvatska/svakodnevno-stizu-stotine-migranata-posjeceno-10-ak-km-sume-uz-granicu-kako-bi-hrvatska-policija-nadzirala-izbjeglice-10385893 (accessed 6. 4. 2021.).

Mountz, Alison. 2017. "Shrinking Spaces of Asylum. Vanishing Points where Geography is Used to Inhibit and Undermine Access to Asylum”. Australian Journal of Human Rights 19/3: 29-50. https://doi.org/10.1080/1323238X.2013.11882133

Mrvoš, Vladimir. 2018. "Nepozvani gosti u susjedstvu. Migranti demolirali planinarski dom Risnjak i vikendice kod Gornjeg Jelenja” (Uninvited Guests in the Vicinity. Migrants Demolish the Risnjak Mountain Lodge and Vacation Homes Near Gornje Jelenje). Novi list, December 6. https://www.novilist.hr/novosti/crna-kronika/ nepozvani-gosti-u-susjedstvu-migranti-demolirali-planinarski-dom-risnjak-i-vikendice-kod-gornjeg-jelenja/ (accessed 6. 4. 2021.).

Pallister-Wilkins, Polly. 2018. "Criminalising Assistance and Solidarity. The ERCI Case and Beyond”. Refugee Observatory. http://refugeeobservatory.aegean.gr/en/criminalising-\%CE\%B1ssistanceand-solidarity-erci-caseand-beyond (accessed 6. 4. 2021.).

Perić, Ivana. 2019. “Garaža za mučenje migranata” (Garage for Torturing Migrants). H-Alter, May 15. https:// www.h-alter.org/vijesti/garaza-za-mucenje-migranata (accessed 6. 4. 2021.).

Petranović, Damir. 2015. "Lopovi, oprez. Big Brother u hrvatskim šumama” (Thieves Beware: Big Brother in Croatian Forests). T portal, December 8. https://www.tportal.hr/vijesti/clanak/lopovi-oprez-big-brother-u-hrvatskim-sumama-20151208 (accessed 6. 4. 2021.). 
Rozakou, Katerina. 2012. "The Biopolitics of Hospitality in Greece. Humanitarianism and the Management of Refugees”. American Ethnologist 39/3: 562-577. https://doi.org/10.1111/j.1548-1425.2012.01381.x

Rozakou, Katerina. 2016. "Socialities of Solidarity. Revisiting the Gift Taboo in Times of Crises”. Social Anthropology 24/2: 185-199. https://doi.org/10.1111/1469-8676.12305

Sapoch, Jack and Hope Baker. s. a. The Role of Technology in Illegal Push-backs from Croatia to Bosnia-Herzegovina and Serbia. Submission to the Special Rapporteur on Contemporary Forms of Racism, Xenophobia and Related Intolerance for the Report on Race, Borders, and Digital Technologies. Border Violence Monitoring Network. https:// www.ohchr.org/Documents/Issues/Racism/SR/RaceBordersDigitalTechnologies/Border\%20Violence\%20 Monitoring\%20Network.pdf (accessed 6. 4. 2021.).

Schindel, Estela. 2019. "Death by 'Nature'. The European Border Regime and the Spatial Production of Slow Violence”. Politics and Space. https://journals.sagepub.com/doi/abs/10.1177/2399654419884948 (accessed 6. 4. 2021.). https://doi.org/10.1177/2399654419884948

s. n. 2019. "Na strani zvijeri (Pismo planinara)" (On the Side of Beasts - Letter from a Hiker). H-Alter, June 18. https://www.h-alter.org/vijesti/na-strani-zvijeri (accessed 6. 4. 2021.).

SRNA. 2020. "Balkanska zima neprijatelj migranata" (Balkan Winter - Enemy of Migrants). N1, December 4. https://ba.n1info.com/vijesti/a492405-ap-balkanska-zima-neprijatelj-migranata/ (accessed 6. 4. 2021.).

Stojić Mitrović, Marta, Nidžara Ahmetašević, Barbara Beznec and Andrej Kurnik. 2020. Dark Sides of Europeanization. Serbia, Bosnia and Herzegovina and the European Border Regime. Belgrade and Ljubljana: Rosa-Luxemburg-Stiftung SEE and Inštitut Časopis za kritiko znanosti. https://www.rosalux.rs/sites/default/files/publications/MITROVIC_Dark_Sides_of_EU_.pdf (accessed 6.4.2021.).

Strategija integriranog upravljanja granicom (Integrated Border Management Strategy). Official gazette "Narodne novine" 91/19. https://narodne-novine.nn.hr/clanci/sluzbeni/full/2019_09_91_1802.html (accessed 6. 4. 2021.).

Tazzioli, Martina. 2018a. "Spy, Track and Archive. The temporality of Visibility in Eurosur and Jora”. Security Dialogue 49/4: 272-288. https: / / doi.org/10.1177/0967010618769812

Tazzioli, Martina. 2018b. "Crimes of Solidarity. Migration and Containment through Rescue" Radical Philosophy. https://www.radicalphilosophy.com/commentary/crimes-of-solidarity (accessed 6. 4. 2021.).

The Asylum Work Group and the Counselling Office of Workers. 2020. Information Submitted under Article 20 of the Convention against Torture and Other Cruel, Inhuman or Degrading Treatment or Punishment Regarding Slovenia's Responsibility for the Torture of Migrants Pushed Back to Croatia. https://drive.google.com/file/d/1RK69OQII WXEE8FOcnfJAYUAA9JL6nFep/view (accessed 6. 4. 2021.).

Večernji list. 2020. "Razbijen dobro organizirani lanac krijumčara. Prebacivali su migrante iz BiH u Hrvatsku” (Wellorganized Smuggling Ring Busted. Used for Transferring Migrants from B\&H to Croatia). Večernji list, May 19, 2020. https://www.vecernji.hr/vijesti/u-zagrebu-otkriveno-zlocinacko-udruzenje-ilegalno-prebacivalimigrante-iz-bih-u-hrvatsku-1403569 (accessed 6. 4. 2021.).

Vijesti.hr. 2019. "Dramatično spašavanje. Migranti zapeli u dubokom snijegu, policajci na rukama nosili pothlađenu djecu" (Dramatic Rescue. Migrants Stuck in Deep Snow, Police Officers Carry Hypothermic Children in Their Arms). Rtl, January 16. https://www.rtl.hr/vijesti-hr/novosti/hrvatska/3321993/krenuli-iz-bih-pjesice-preko-pljesevice-mali-migranti-promzrli-i-kolabirali-odvezli-ih-u-gospicku-bolnicu/ (accessed 6. 4. 2021.).

Vlašić, Anđelko. 2019. "Stanje šuma u Slavoniji za osmanske vladavine (1526. - 1691.)” (The State of Forests in Slavonia During Ottoman Rule (1526-1691)). In Prema povijesti slavonskih šuma (According to the History of Slavonian Forests). Robert Skenderović and Dinko Župan, ed. Slavonski Brod: Hrvatski institut za povijest, Podružnica za povijest Slavonije, Srijema i Baranje, 70-90.

Vlada Republike Hrvatske (Croatian Government). 2014. "Odluka o zaprječivanju cestovnih komunikacija i putova na državnoj granici s Bosnom i Hercegovinom i Republikom Srbijom” (Decision on Obstruction of Road Communications and Paths on the State Border with Bosnia and Herzegovina and the Republic of Serbia). Official gazette "Narodne novine" 55/14. https://narodne-novine.nn.hr/clanci/sluzbeni/2014_05_55_1036. html (accessed 6. 4. 2021.).

Vlada Republike Hrvatske (Croatian Government). 2018a. XIII. Izvješće o provedbi integriranog upravljanja granicom (13th Report on the Implementation of Integrated Border Management). https://vlada.gov.hr/UserDocsImages//2016/Sjednice/2019/Lipanj/161\%20sjednica\%20VRH//161\%20-\%2022.1.pdf (accessed 6. 4. 2021.).

Vlada Republike Hrvatske (Croatian Government). 2018b. “Odluka o dopuni Odluke o zaprječivanju cestovnih komunikacija i putova na državnoj granici s Bosnom i Hercegovinom i Republikom Srbijom” (Decision on Amendments to the Decision on Obstruction of Road Communications and Paths on the State Border with Bosnia and Herzegovina and the Republic of Serbia). Official gazette "Narodne novine" 97/18. https://narodnenovine.nn.hr/clanci/sluzbeni/2018_11_97_1874.html (accessed 6.4.2021.).

Vlada Republike Hrvatske (Croatian Government). 2019. XIII Izvješće o provedbi Strategije integriranog upravljanja granicom (13th Report on the Implementation of Integrated Border Management Strategy). https://vlada.gov.hr/ 
UserDocsImages//2016/Sjednice/2019/Lipanj/161\%20sjednica\%20VRH//161\%20-\%2022.1.pdf (accessed 6. 4. 2021.).

Walters, William. 2016. "Live Governance, Borders, and the Time-space of the Situation. EUROSUR and the Genealogy of Bordering in Europe”. Comparative European Politics 15/5: 794-817. https://doi.org/10.1057/ s41295-016-0083-5

Zakon o šumama (Forest Act). 2018. Official gazette "Narodne novine" 68/18. https://narodne-novine.nn.hr/clanci/ sluzbeni/2018_07_68_1392.html (accessed 6.4.2021.).

Zorn, Jelka. 2021. "Evropski mejni režim. Tihotapljenje ljudi in paradoks kriminalizacije solidarnosti” (European border regime. The smuggling of people and the paradox of the criminalization of solidarity). Dve domovini / Two Homelands 53/1: 81-98. https://ojs.zrc-sazu.si/twohomelands/article/view/9532 (accessed 6. 4. 2021.). https://doi.org/10.3986/dd.2021.1.06

Žada, Ivan. 2019. "Pripreme za Schengen. Buldožerima čiste granicu! Građani negoduju, a iz policije kažu: 'Sve se radi s dozvolom' - Ili ne?” (Preparations for Schengen. Bulldozers Clearing the Border! Citizens Indignant, Police Says: 'Everything is done with permits' - Or not?), Rtl, November 11. https://www.rtl.hr/vijesti-hr/ potraga/3596583/buldozerima-ciste-granicu-gradjani-negoduju-a-iz-policije-kazu-sve-se-radi-s-dozvolomili-ne/ (accessed 6. 4. 2021.).

Žic, Davor. s. a. "U oku kamere. Umjesto medvjeda, lovci 'ulovili' poveću grupu migranata” (In the Eye of the Camera. Instead of Bears, Hunters 'Catch' a Large Group of Migrants). https://poduckun.net/u-oku-kamere-umjesto-medvjeda-lovci-ulovili-povecu-grupu-migranata/ (accessed 6. 4. 2021.).

\section{Forest, forest, forest. Sometimes we sleep. Walking, sleep, walking, sleep. It's dangerous on this way. Naoružani migrantski krajolici na periferiji Europske unije}

Skriveni migrantski putevi kroz Hrvatsku vode, među ostalim, i kroz šumske predjele koji uključuju šumska područja uz državne granice, ali i šume u unutrašnjosti teritorija. Šume se može vidjeti kao, makar i surova, skloništa za migrante ili kao zelene tunele koji vode do željenih odredišta, ali i kao poprišta stradanja i nasilja. Članak šumama o kojima je riječ pristupa kao krajolicima koji su od nepristranog prirodnog okoliša pretvoreni u aktivne činitelje stvaranja i održavanja režima kontrole granice, odvraćanja i istjerivanja neželjenih migranata. Na temelju višegodišnjih terenskih istraživanja i javno dostupnih (arhivskih, medijskih i drugih) izvora nastojimo dokumentirati, interpretirati i povezati predmete i prakse koji sudjeluju u konstruiranju šume kao neprijateljskog terena i opasnog okruženja za migrante i kao važnog elementa u kontroli neželjenih migracija. Riječ je s jedne strane o predmetima i praksama kojima se intervenira $u$ šume, poput postavljanja kamera ili sječe stabala te $\mathrm{s}$ druge strane o intervencijama u šumama, poput policijskog presretanja ili protjerivanja. Osim o tim intervencijama izvana u kontekstu kreiranja šume kao opasnog okruženja može se govoriti i o ulozi same prirode i njezinih osobina, kao i o uzrocima migrantskog bivanja u prirodi. Iako se na prvi pogled čini da ljudi u pokretu sami biraju šumu za mjesto i trasu svojeg kretanja, oni su politikama isključenja (viznim režimom, azilnim sustavom i dr.) u nju gurnuti i istjerani. Time se, u konačnici, $i$ šume u Hrvatskoj svrstavaju u naoružane krajolike isključenja i smrti poput onih pustinjskih (npr. De León 2015), planinskih (Del Biaggio et al. 2020), maritimnih (npr. Albahari 2015) ili arhipelaških (npr. Mountz 2017).

Ključne riječi: šume, izbjeglice, migranti, naoružani krajolici, pušbek, Hrvatska, europski režim granice 